\title{
Inclusion of Cephalexin in COVID-19 Treatment Combinations May Prevent Lung Involvement in Mild Infections: A Case Report with Pharmacological Genomics Perspective
}

\author{
Amir Khodavirdipour ${ }^{1,2}$ \\ ${ }^{1}$ Department of Biology, Faculty of Natural Sciences, University of \\ Tabriz, Tabriz, Iran \\ 2 Division of Human Genetics, Department of Anatomy, St. John's \\ National Academy of Health, Bangalore, Karnataka, India
}

\begin{abstract}
Address for correspondence Amir Khodavirdipour, PhD, Department of Biology, Faculty of Natural Sciences, University of Tabriz, Tabriz 5166616471, Iran (e-mail: amir_kvp@yahoo.com).
\end{abstract}

\author{
Abstract \\ Keywords \\ - COVID-19 treatment \\ - SARS-CoV-2 \\ - cephalexin \\ - omeprazole
}

Novel coronavirus disease 2019 (COVID-19) is caused by a nonsegmented positive sense RNA, enveloped RNA virus that belongs to the family of $\beta$-coronaviridae. This virus shall cause acute respiratory distress syndrome (ARDS) which consequently leads to breathing difficulty and need to admit to intensive care units (ICUs). The current conventional treatment combination in most of the hospitals in Iran includes azithromycin 500 + naproxen 500 + vitamin C 1,000+Zinc + vitamin D3 1,000. In this case reports $(n=4)$, we would like to report significant findings in course of COVID-19 treatment reported to our clinic on August 8 and 9, 2020; patients presented as walk in and were advised house isolation and complete bed rest as there were no signs of lung involvement and their overall condition was stable. By the inclusion of cephalexin 500 in treatment combination, patients who received cephalexin 500 for 5 days along with other medicines did not develop any lung involvement and breathing complications. Cephalexin is the gold standard in upper and lower respiratory tract infections and here also shall play a vital role besides other conventional therapies. Azithromycin is a macrodial antibiotic working via the $A B C B 1$ gene pathway. As of date, there is no clear evidence of pharmacogenomics data in COVID-19 patients. More research needs to be performed in COVID-19 before any sort of pharmacogenomics tests could be advised.

\section{Introduction}

Novel coronavirus disease 2019(COVID-19) lately named the first pandemic disease of the 21 st century. As of January 31, 2021, mortality rate reported above 2,225,000 cases worldwide and numbers are growing rapidly due to the latest dreadful mutations from the United Kingdom to Brazil and South Africa. ${ }^{1}$ Disease transmission from human-to-human spread via air droplets by sneezing or coughing from a

published online March 22, 2021
DOI https://doi.org/ $10.1055 / \mathrm{s}-0041-1726461$ ISSN 2699-9404. positive person. ${ }^{2}$ To date, prevention is named as the best containment way. People should obey hygienic protocols by following health tips such as no physical contact, using a face mask, washing hands, and keep a safe distance from people in public areas. ${ }^{3}$ Diagnosis shall be confirmed by molecular tests (polymerase chain reaction [PCR]) and computed tomography (CT) scans and chest X-rays in case of lung involvement. ${ }^{4}$ Reported mortality is different by countries and depends on the way they treat or people following the

\section{(c) 2021. The Author(s).}

This is an open access article published by Thieme under the terms of the Creative Commons Attribution License, permitting unrestricted use, distribution, and reproduction so long as the original work is properly cited. (https://creativecommons.org/licenses/by/4.0/) Georg Thieme Verlag KG, Rüdigerstraße 14, 70469 Stuttgart, Germany 
Table 1 Timeline of signs and symptoms of all four patients and treatment combinations advised

\begin{tabular}{|c|c|c|c|c|}
\hline Timeline & $\mathrm{P} 1-\mathrm{M} / 31$ & $\mathrm{P} 2-\mathrm{M} / 35$ & P3-M/33 & $\mathrm{P} 4-\mathrm{M} / 36$ \\
\hline Day 1 & Sore throat & Fever, headache & Sore throat & Sore throat \\
\hline Day 2 & $\begin{array}{l}\text { Fatigue, sore } \\
\text { throat, runny nose }\end{array}$ & $\begin{array}{l}\text { Headache, } \\
\text { sore throat, fatigue }\end{array}$ & $\begin{array}{l}\text { Shivering, high fever, } \\
\text { runny nose, PCR+ }\end{array}$ & $\begin{array}{l}\text { Fever, anosmia, runny } \\
\text { nose }\end{array}$ \\
\hline Day 3 & $\mathrm{PCR}+$ & $\mathrm{PCR}+$, Stomach ache & $\begin{array}{l}\text { diarrhea, body ache, } \\
\text { anosmia, ageusia, } \\
\text { mild fever, CT no lung } \\
\text { involvement }\end{array}$ & $\begin{array}{l}\text { Severe sore throat } \\
\text { high fever, severe } \\
\text { diarrhea, PCR+ }\end{array}$ \\
\hline Day 4 & $\begin{array}{l}\text { No cough, no body ache, } \\
\text { sore throat, } \\
\text { mild fatigue, anosmia }\end{array}$ & $\begin{array}{l}\text { CT no lung } \\
\text { involvement, anosmia }\end{array}$ & $\begin{array}{l}\text { Severe fatigue, the } \\
\text { coughing started }\end{array}$ & $\begin{array}{l}\text { Stomach ache, fatigue, } \\
\text { vertigo, coughing } \\
\text { started }\end{array}$ \\
\hline Day 5 & $\begin{array}{l}\text { CT shows no } \\
\text { lung involvement }\end{array}$ & $\begin{array}{l}\text { Stomach ache, } \\
\text { diarrhea, fatigue }\end{array}$ & $\begin{array}{l}\text { Heavy diarrhea, severe } \\
\text { fatigue, body pain, } \\
\text { CT 5\% lung } \\
\text { involvement }\end{array}$ & - \\
\hline Day 6 & Start to recovery & Mild fatigue & - & $\begin{array}{l}\text { CT showing 3\% } \\
\text { involvement, } P C R+\end{array}$ \\
\hline Day 7 & - & Start to recovery & - & - \\
\hline Day 8 & - & - & - & $\begin{array}{l}\text { Smelling sensation } \\
\text { return slowly }\end{array}$ \\
\hline Day 9 & - & - & - & - \\
\hline Day 10 & - & - & Start to recovery & - \\
\hline Day 11 & - & - & - & Start to recovery \\
\hline Day 12 & - & - & PCR+ & - \\
\hline Day 15 & PCR+ & PCR+ & - & PCR+ \\
\hline $\begin{array}{l}\text { Treatment } \\
\text { combination }\end{array}$ & $\begin{array}{l}\text { Azithromycin } 500 \\
\text { Cephalexin } 500 \\
\text { Naproxen } 500 \\
\text { Panadol cold flu } \\
\text { Zinc } \\
\text { Vitamin C } 1,000 \\
\text { Vitamin D } 1,000\end{array}$ & $\begin{array}{l}\text { Azithromycin } 500 \\
\text { Cephalexin } 500 \\
\text { Naproxen } 500 \\
\text { Omeprazole } 20 \\
\text { Zinc } \\
\text { Vitamin C } 500 \\
\text { D3 } 1,000\end{array}$ & $\begin{array}{l}\text { Azithromycin } 500 \\
\text { Naproxen 500, } \\
\text { Panadol cold flu } \\
\text { Vitamin C } 1,000 \\
\text { Vitamin D3 } 1,000 \\
\text { Zinc }\end{array}$ & $\begin{array}{l}\text { Azithromycin } 500 \\
\text { Naproxen } 500 \\
\text { Panadol cold flu } \\
\text { Vitamin C } 1,000 \\
\text { Vitamin D3 } 1,000 \\
\text { Zinc }\end{array}$ \\
\hline
\end{tabular}

Abbreviations: $C T$, computed tomography; M, male; P, patient; PCR, polymerase chain reaction.

Note: No patients admitted to ICU. All advised to rest at home.

Interestingly all of them felt increase in appetite after next 48 hours of first sign of disease.

protocols. People with jobs in public sectors are the most at risk including doctors, nurses, bank tellers, public transport drivers, and others.

\section{Patients and Methods}

Four self-reported young males under age 36 years were included in this study. All of them working in the public sector and equipped daily with face mask, face shield, and gloves, and all samples' exposure levels estimated the same based on the history taken. Due to the Red status issued by the Health Ministry of Iran for more than $75 \%$ of Iranian provinces, ${ }^{5}$ after the preliminary examination, the samples were taken for the molecular analysis and medication treatment course started and advised for house isolation and complete bed rest as there was no sign of lung involvement. The full history of patients and their advised treatment regimen are available in -Table $\mathbf{1}$. Interestingly, all of them felt an increase in appetite after the next 48 hours of the first sign of disease. As per World Health Organization (WHO) protocol, as there is no precise treatment option for COVID-19, symptomatic management as per the patient's clinical symptoms and condition is the only choice.

\section{Discussion}

Public sector exposure to COVID-19 is one of the main concerns of transmission after deciding to reopen after March to April quarantine in Iran. At the beginning of COVID-19 in Iran, there was not enough public awareness and protection against the virus. This study showing that not only older people and/or with secondary health problems like cardiovascular diseases (CVD) or kidney diseases can infect but also a young and healthy adult with no previous health issues can also be infected by the virus. All four patients reported positive in their molecular real-time PCR 


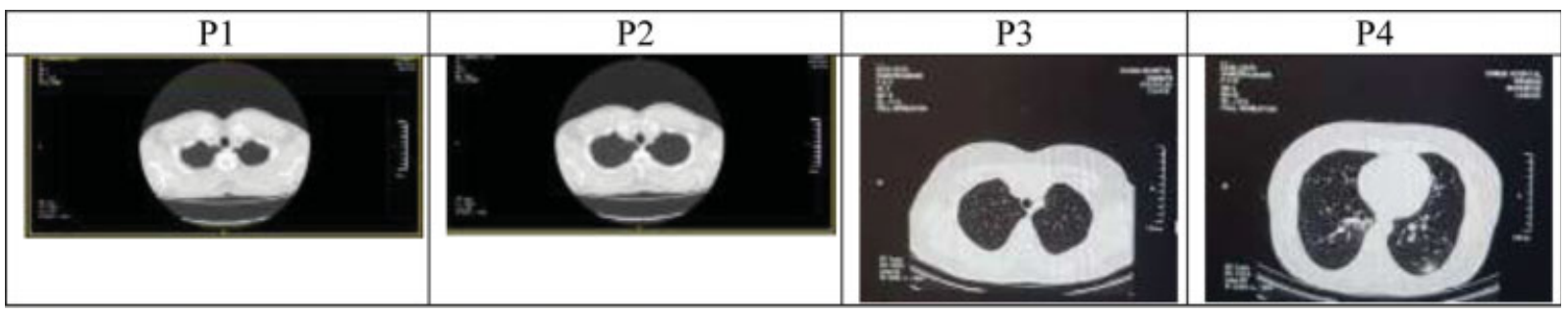

Fig. 1 Results of the CT scans illustrated that the patients who were under cephalexin administration along with other conventional therapies showed no lung involvement and breathing complications (patients 1 and 2). Patients 3 and 4 undergone regular symptomatic management regimens. CT, computed tomography; P, patient.

test, while patients 1,2 , and 3 showed no lung involvement in their first CT and patient 4 showed mild lung involvement (-Fig. 1). The medication treatment course started on the days 2 and 3 for all four patients. Patients 1 and 2 were advised to take cephalexin 500, one capsule each at every 6 hours for 5 days for cystic pimple and perioral dermatitis, respectively. Despite being PCR positive, none of them developed the breathing complications or lung involvement by COVID-19 and felt overall amelioration on the days 6 and 7 but the other two patients who followed the routine medicinal regimen, felt the same after almost 2 weeks. Jain et al reported that cephalexin can be useful against upper respiratory tract infection. ${ }^{6}$ Khodavirdipour et al in a very latest update listed all the treatment combinations suggested against the COVID- $19 ;{ }^{7}$ so, now this breakthrough can be a great help in the fight against COVID-19 for faster recovery time and also keeping lung safe and protect from any sort of complications. Need to mention that patient 2 prescribed to take omeprazole due to his heartburn and stomach ache. Bojkova et al in their recent paper elucidated that omeprazole above the usual clinical dose showing the anti-severe acute respiratory syndrome-coronavirus-2 (SARS-CoV-2) protective capacity. ${ }^{8}$ The current study experienced some limitations including a low number of samples. Due to the high seriousness and importance of the matter and triumph in protecting the lungs of the patients, our team felt these findings can be road maps for other colleagues worldwide to save people's lives.

\section{Pharmacogenomics}

Cephalexin is a quick absorber and does it via the intestine through the $\mathrm{H}^{+}$/depipetide transporter PEPT1 gene product (solute carrier family 15 member 1 protein) and reabsorbed chiefly from the kidney by PEPT2 gene product at the basolateral membrane of proximal tubule cells of the renal system. Reportedly, a specific variant of SLC15A1 showing a remarkable decreased in cephalexin uptake in cells that are transfected. ${ }^{9}$

One of the stars of the macrolide antibacterial agent category is azithromycin which has significant anti-inflammatory characteristics. Azithromycin pharmacokinetics elucidate that its activity under the control of P-glycoprotein transported is encoded by the $A B C B 1$ gene. The variations in $A B C B 1$ gene such as rs1045642CC/rs2032582GG/rs1045642TT and rs2032582TT. ${ }^{10}$

\section{Conclusion}

Despite being one of the oldest and famous antibiotics marketed by 1969 , cephalexin is suggested to be administered next to other antibacterial drugs, such as azithromycin, in cases of viral infections such as COVID-19. By considering the above findings, adding cephalexin 500 or even omeprazole to the conventional therapy combination can be worthwhile as the burden of COVID-19 becoming unbearable day by day, as the number of positive cases surges. The situation turning to be exhaustive in terms of human resources, economically and also mentally for health care services, governments, affected individuals, and their families.

As of date, there is no clear evidence of pharmacogenomics data in COVID-19 patients. But there are credible mechanisms which show that the genetic makeup of each person can play critical role in his/her battle against COVID-19. More research needs to be performed in COVID-19 before any sort of pharmacogenomic tests could be advised.

\section{Funding}

None.

Conflict of Interest

None declared.

\section{References}

1 Coronavirus live update. Accessed August 26, 2020 at: https:// www.worldometers.info/coronavirus

2 Lewis D. Mounting evidence suggests coronavirus is airborne-but health advice has not caught up. Nature 2020;583 (7817):510-513

3 How to protect yourself \& others. Accessed August 26, 2020 at: https://www.cdc.gov/coronavirus/2019-ncov/prevent-getting-sick/prevention.html

4 Alsuliman T, Sulaiman R, Ismail S, Srour M, Alrstom A. COVID-19 paraclinical diagnostic tools: updates and future trends. Curr Res Transl Med 2020;68(03):83-91

5 Iran's latest coronavirus condition; 15 provinces red status, dangerous autumn ahead. Accessed August 30, 2020 at: https://www.iranfocus.com/en/life-in-iran/34724-iran-s-latestcoronavirus-condition-15-provinces-red-status-dangerous-autumn-ahead

6 Jain N, Lodha R, Kabra SK. Upper respiratory tract infections. Indian J Pediatr 2001;68(12):1135-1138

7 Khodavirdipour A, Keramat F, Hashemi SH, Alikhani MY. SARS-CoV-2; from vaccine development to drug 
discovery and prevention guidelines. AIMS Mol Sci 2020;7 (03): 281

8 Bojkova D, McGreig JE, McLaughlin KM, et al. SARS-CoV-2 and SARS-CoV differ in their cell tropism and drug sensitivity profiles. bioRxiv 2020
9 Anderle P, Nielsen CU, Pinsonneault J, Krog PL, Brodin B, Sadée W. Genetic variants of the human dipeptide transporter PEPT1. J Pharmacol Exp Ther 2006;316(02):636-646

10 Takahashi T, Luzum JA, Nicol MR, Jacobson PA. Pharmacogenomics of COVID-19 therapies. Genomic Med 2020;5:35 